Barbara Krupa

Biblioteka Uniwersytetu Stanforda, Stanford, Stany Zjednoczone Ameryki

krupa@stanford.edu

ORCID 0000-0002-7085-9211

\title{
Działalność Roy Publishers w Nowym Jorku w latach 1941-1960 jako kontynuacja tradycji przedwojennego Towarzystwa Wydawniczego „Rój”
}

\author{
Abstract \\ The activities of Roy Publishers in New York during \\ 1941-1960 - a continuation of the pre-war Publishing Society \\ "Rój" tradition
}

The article discusses the publishing activities of Roy Publishers in New York from 1940 to the 1960s, particularly its impact on popularizing Polish literature and information about Poland in the U.S. The publishing house continued the tradition of the former house, named "Rój", which was active during 1924-1940 in Warsaw and established by Melchior Wańkowicz, then managed together with Marian Kister. The article is based on the materials from the publishing house archive, now held at Stanford University Libraries, a valuable research source on the émigré cultural heritage of the $2^{\text {nd }}$ Republic of Poland.

Key words: Publishing House "Rój" - Roy Publishers - Polish emigre publishing houses Polish interwar literature - Literary translation awards - Marian Kister - Hanna Kister.

Słowa kluczowe: Towarzystwo Wydawnicze „Rój” - Roy Publishers - polskie oficyny wydawnicze na emigracji - polska literatura międzywojenna - nagrody za przekłady literackie Marian Kister - Hanna Kister.

„Z Badań nad Książką i Księgozbiorami Historycznymi” - Udział zagranicznych recenzentów w ocenie publikacji; Stworzenie anglojęzycznej wersji wydawniczej publikacji; Digitalizacja tomów archiwalnych rocznika w celu zapewnienia otwartego dostępu do nich przez Internet oraz wdrożenie i utrzymanie cyfrowej platformy redakcyjnej - zadanie finansowane w ramach umowy nr 653/P-DUN/2019 ze środków Ministra Nauki i Szkolnictwa Wyższego przeznaczonych na działalność upowszechniającą naukę. 


\section{Kolekcja Roy Publishers Records}

Kolekcja archiwum została zakupiona przez Bibliotekę Główną Uniwersytetu Stanforda w Kalifornii, w sierpniu 2015 r. Składają się na nią: korespondencja z prominentnymi polskimi pisarzami i artystami dwudziestolecia międzywojennego, m.in.: Aleksandrem Jantą-Połczyńskim, Zofią Kossak-Szczucką, Marianem Hemarem, Marią Kuncewiczową, Stanisławem Lamem, Melchiorem Wańkowiczem, Rulką Langer, Ireną Lorentowicz, Feliksem Topolskim, Teodorem Parnickim, Ksawerym Pruszyńskim, Kazimierzem Wierzyńskim; maszynopisy utworów literackich; korespondencja z polskimi i amerykańskimi instytucjami rządowymi, i innymi wydawnictwami; materiały wystawowe i promocyjne; druki efemeryczne; zestawienia bibliograficzne; recenzje; materiały dotyczące praw autorskich; kilka akwarel, m.in. I. Lorentowicz. Materiały te są dowodem na utrzymywanie ścisłego związku wydawnictwa z Polską, zarówno z pisarzami, którzy tworzyli w kraju i na emigracji, jak i z polskimi i emigracyjnymi wydawnictwami. Wybór publikowanej literatury, widoczny w zachowanych katalogach i listach wydawniczych, zwłaszcza w początkowym okresie emigracyjnym, świadczy o zaangażowaniu w promocję polskiej literatury, kultury i nauki. Inne materiały źródłowe, takie jak: rozległa korespondencja z polskimi i amerykańskimi organizacjami i stowarzyszeniami, zaproszenia czy inne dostępne informacje, wskazują na dużą aktywność właścicieli, Mariana i Hanny Kisterów, na polu życia kulturalnego Polonii amerykańskiej, która przejawia się w działaniach na rzecz kultywowania polskich tradycji oraz wspieraniu imprez polonijnych przez tę instytucję.

Obok korespondencji służbowej, w tym ksiąg rachunkowych, w archiwum znajduje się wiele listów prywatnych (łącznie z korespondencją M. Kistera z 1918 r.), kartki pocztowe oraz telegramy adresowane do M. i H. Kisterów, a także kopie odpowiedzi. W skład dokumentów osobistych wchodzi ponad 100 biało-czarnych i kolorowych zdjęć, paszporty, dokumenty imigracyjne, certyfikaty, dokumenty podatkowe oraz materiały związane ze śmiercią M. Kistera w 1958 r. - wycinki z prasy, kondolencje i wspomnienia.

$\mathrm{W}$ archiwum znajduje się około 300 książek, wydanych po polsku lub angielsku oraz publikacje zaprzyjaźnionych autorów, teksty opowiadań, ilustracje i okładki książek. Około 30 z nich ma dedykacje i autografy. Kolekcja jest częścią zbiorów Special Collection and University Archives w Stanford University Libraries. Nie jest obecnie dostępna dla użytkowników, ponieważ nie jest opracowana ${ }^{1}$.

1 Department of Special Collections and University Archives Stanford University Libraries [dalej SPC SUL], catalog number M2074, Roy Publishers records, undated, [stan z lutego 2017 r.]. 


\section{Warszawski „Rój”}

Początki wydawnictwa opisała $\mathrm{H}$. Kister w liście do prawnika w Nowym Jorku z 12 VIII 1964 r.:

Towarzystwo Wydawnicze „Rój” zostało założone przez Melchiora Wańkowicza, barona Brynka i p. Tworkowskiego. Kiedy Marian [Kister] przyszedł do Roju na dyrektora na okres próbny, ażeby Rój usynować [uzdrowić-przyp. autorki] (1924) Rój istniał zaledwie kilka miesięcy, kapitał zakładowy został pochłonięty przez reklamę i organizację administracji. Po sześciu miesiącach próbnych Marian i Wańkowicz założyli spółkę wewnętrzną w Roju pod nazwą KIWA i włożyli po 7500 złotych (Brynk i Tworkowski nie chcieli więcej ryzykować). Spółka ta i pasja wydawnicza Mariana wkrótce dały rezultaty, wykupiono udziały, [z których] 2/3 wziął Wańkowicz, a Marian dostał 1/32.

Wspólnie z wydawnictwem Arcta i Domem Książki Polskiej „Rój” publikował najpierw serię (zarejestrowaną jako czasopismo) pod nazwą „Biblioteczka Historyczno-Geograficzna"’3. Z czasem czasopismo to przekształciło się w niezależne wydawnictwo, którego właścicielami od 1926 r. byli Wańkowicz (1892-1974) i Kister (1897-1958). Siedziba „Roju” mieściła się w oficynie Towarzystwa Kredytowego Ziemskiego przy ulicy Kredytowej 1 w Warszawie.

Na początku Kister odpowiadał wyłącznie za stronę techniczną i finansową wydawnictwa, a Wańkowicz - za literacką, ale sytuacja szybko się zmieniła i to Kister podejmował decyzje, jakie tytuły powinny ukazać się drukiem. Do zespołu dołączyła również żona Kistera - Hanna (1902-1997), pełniąc różne obowiązki administracyjne.

Kister różnił się znacznie od wydawców okresu międzywojennego. Jak wspomina Kazimierz Wierzyński:

Marian Kister nie był podobny do żadnego ze znanych mi wydawców. Nie miał arystokratyzmu Jakuba Mortkowicza, profesorskiej powagi Jana Piątka, encyklopedyczności Stanisława Lema. [...] Wydawca - cygan lubił siedzieć w kawiarni całymi godzinami. Lubił gwarzyć bez końca z pisarzami i przyjaciółmi. Lubił anegdoty, wice, powiedzonka. Wiedział o bliźnich jeśli nie wszystko, to bardzo dużo. Pół czarnej w Ziemiańskiej należało do jego konieczności życiowych ${ }^{5}$.

Firma stała się największą w Polsce oficyną wydawniczą, publikującą około 30 pozycji miesięcznie, wśród których były zarówno książki masowe,

2 SPC SUL, M2074, Roy Publishers records. H. Kister, list z 12 VIII 1964 r.

3 H. Kister, Pegazy na Kredytowej: wspomnienia, Warszawa 1980, s. 20.

4 Ziemiańska, a właściwie Mała Ziemiańska, znana warszawska kawiarnia okresu dwudziestolecia międzywojennego, miejsce spotkań inteligencji, pisarzy, poetów, artystów i profesorów pobliskiego Uniwersytetu Warszawskiego. Nazwa wzięła się najprawdopodobniej z sąsiedztwa Towarzystwa Kredytowego Ziemskiego oraz z pierwotnie małej sali kawiarni.

5 SPC SUL, M2074, Roy Publishers records. K. Wierzyński, Wspomnienie o Marianie Kisterze, s. 1 . 
tanie, o niskiej jakości wydawniczej, jak i dzieła najwybitniejszych pisarzy polskich i zagranicznych oraz reportaże i publicystyka. W wywiadzie udzielonym „Wiadomościom Literackim” 1934 r. z okazji 10-lecia wydawnictwa, Kister powiedział:

«Rój» począł się z pasji o szerokie czytelnictwo, z walki z szundliteratura (literaturą brukową - przyp. autorki). Niech pan nie zapomina, że przed dziesięciu laty, kiedy powstał, literatura ta - trudno w to wprost uwierzyć - stanowiła według statystyki urzędowej $26 \%$ całej polskiej produkcji wydawniczej. Owe $26 \%$ było zupełnie poza obrotem księgarskim, nie wliczano w nie wydawnictw beletrystycznych ani jako tako znanych autorów, ani jako tako znanych firm księgarskich. «Rój» jako odtrutkę dał przede wszystkiem swoją żółtą trzydziestogroszową bibljoteczkę, debiutującą niesłychanymi tytułami, jak Czarna msza Tuwima ${ }^{6}$.

Wydawnictwo publikowało autorów polskich okresu międzywojennego: Wacława Sieroszewskiego, Ewę Szelburg-Zarembinę, Wandę Melcer, Halinę Marię Dąbrowolską, Irenę Krzywicką, Irenę Zarzycką, Mieczysława Bohdana Lepeckiego, Jana Waśniewskiego (w trzyzłotowej serii), Bruno Schulza, Juliana Tuwima, Tadeusza Boya-Żeleńskiego, Juliusza Kadena-Bandrowskiego, Witolda Gombrowicza, Stanisława Vincenza, Tadeusza Dołęgę-Mostowicza, Brunona Jasieńskiego, Karola Irzykowskiego, Jana Parandowskiego, Helenę Boguszewską, Marię Ukniewską, Polę Gojawiczyńską, Czesława Centkiewicza, Arkadego Fiedlera, Karola Irzykowskiego, Antoniego Słonimskiego, Jana Lechonia, Józefa Wittlina, Izaaka Singera, Sergiusza Piaseckiego. Jak wspomina Wierzyński,

Dla młodych pisarzy polskich miał [Marian Kister - przyp. autorki] zawsze otwarte serce.

Do jego faworytów należeli: Maria Kuncewiczowa, Adolf Rudnicki, Ksawery Pruszyński,

Teodor Parnicki, Pola Gojawiczyńska, Jerzy Andrzejewski, Bruno Schulz. [...] [Rój] wprowadził do literatury polskiej wielu znakomitych obcych autorów. W «Roju» ukazał się po raz pierwszy James Joyce, Proust, Kafka, Bertrand Russel, Malraux, Hemingway, tam wyszły wielotomowe rzeczy Tomasza Manna, Sigrid Undset, Johna Galsworthy, Jules Romaines'a, Rogera Martin du Gard, Aldousa Huxley'a i wielu innych7.

Autorami „Roju” byli także znakomici pisarze europejscy i amerykańscy, m.in.: Stefan Zweig, Michaił Szołochow, Sigrid Undset, Marcel Proust, Tomasz Mann, Sinclair Lewis, John Steinbeck, Jack London, Pearl Buck, O. Henry, William John Locke, Erich Remarque, Herman Hesse oraz John Galsworthy. „Rój” spełniał misję przedstawienia polskiemu czytelnikowi książek, które do tej pory były mu niedostępne oraz umożliwiał polskim pisarzom kontakt z kolegami po piórze, o czym pisze we Wspomnieniu o moim wydawcy (fragment

$6 \quad$ [kr.], Zastużone dziesięciolecie: wywiad z Tow. Wydawniczem „Rój”, „Wiadomości Literackie" 1935 , nr 10, s. 5.

7 SPC SUL, M2074, Roy Publishers records. K. Wierzyński, Wspomnienie..., s. 2. 
pamiętnika) A. Janta, polski emigracyjny prozaik, poeta, dziennikarz, publicysta i thumacz:

Katalogi «Roju» kwitły tytułami nowych dzieł literatury, nie tylko polskiej. «Rój» stał się kuźnią związków, wprowadzających w literacką świadomość i pracę ówczesnej Polski całe zespoły dzieł obcych, pozwalając wąskiemu może, ale tym bardziej ciekawemu świata kręgowi czytelników na ten szeroki ze światem kontakt, jaki dają tłumaczenia bieżących, a uwieńczonych powodzeniem dzieł ze wszystkich języków.

Ameryka w tym okresie trzymała wśród wydawnictw rojowskich prym. Zdarzało mi się nieraz w spotkaniach z pisarzami Ameryki przed wojną, z Dreiserem, z Carl van Vechtenem, z Upton Sinclairem, z Glenway Wescottem, że wyciagali po paru chwilach rozmowy tom polskiego tłumaczenia którejś z ich książek, po okładce łatwo i na odległość dającej się określić jako produkcja «Roju» - i ta ich polska książka była dla mnie, jako dla pisarza z Polski, najlepszych do nich wprowadzeniem ${ }^{8}$.

Od roku 1932 do 1939 firma wydawała „Nowości Literackie”, miesięcznik o charakterze informacyjno-reklamowym ${ }^{9}$. Wydawnictwo zarabiało na drogich książkach, wydawanych w seriach: ,na Dziełach XX wieku, na Dokumentach epoki, na książkach socjologicznych i podróżniczych""10.

„Rój” był niezwykle płodnym wydawnictwem, co potwierdza statystyka. Przez 10 lat, od 1924 do 1934 r., opublikował półtora tysiąca dzieł, z których średnio połowę stanowiły utwory literatury obcej, i tak np. w 1933 r. wydał 43 polskie tytuły, 17 angielskich, siedem francuskich, siedem niemieckich, sześć amerykańskich, cztery rosyjskie, dwa żydowskie, cztery inne - razem 90. W kolejnym, 1934 r. - 41 polskich, 24 angielskich, pięć francuskich, cztery niemieckie, pięć amerykańskich, 12 rosyjskich, jeden żydowski i jeden inny razem 93. Kolejne lata przyniosły Akacje kwitna Debory Vogel, dwujęzycznej pisarki żydowskiej, piszącej po polsku i w jidysz, Bogusława Kuczyńskiego Kobiety na drodze, epos o Huculszczyźnie Stanisława Vincenza, a w serii „Podróże i wyprawy” książki Jana Bersona Otmara, A. Janty-Połczyńskiego, K. Pruszyńskiego, A. Fiedlera, autobiografie Marka Twaina i Orsona Wellsa i pamiętniki Lloyda George'a, Wszechideat filozofa Rudolfa Marii Holzapfla. Wydawnictwo opublikowało także wielkie albumowe dzieło pióra Mieczysława Lepeckiego, byłego adiutanta marszałka Józefa Piłsudskiego, pt. Piłsudski na Syberii z wielobarwnymi planszami Zygmunta Czermańskiego.

8 A. Janta, Wspomnieniu o moim wydawcy (fragment pamiętnika), „Tydzień Polski”, Londyn, z 21 IX 1968 r., s. 6.

9 B. Krupa, M. Nafpaktitis, Polonika w Bibliotece Uniwersytetu Stanforda w Kalifornii: unikalne kolekcje, trudności w gromadzeniu i udostępnianiu, „Z Badań nad Książką i Księgozbiorami Historycznymi" 2017, t. specjalny: Polonika w zbiorach obcych, red. nauk. J. Puchalski, A. Chamera-Nowak i D. Pietrzkiewicz, Warszawa 2017, s. 562-563.

10 SPC SUL, M2074, Roy Publishers records. [kr.] Zasłużone... 
„Rój” nie przestał istnieć po wybuchu wojny w 1939 r. Jego dalsze losy opisała przede wszystkim H. Kister w Pegazach na Kredytowej wydanych przez PIW w 1980 r. oraz J. Wittlin, jeden z autorów i przyjaciół publikowanych przez „Rój”, we wspomnieniowym artykule napisanym na cześć tej instytucji i wydrukowanym w londyńskich „Wiadomościach” 7 VI 1964 r.:

Gdy wybuchła wojna, pan Marian znajdował się w Paryżu. Ale sam. Pani Hanna została w Warszawie i dopiero wiosną 1940 roku, po różnych perypetiach, dotarła do Paryża ${ }^{11}$. Tam czekała już na nią praca w nowym wydawnictwie ${ }^{12}$, które zmontował pan Marian do spółki z pewną poważną firmą francuską. Rozpoczął wydawanie książek autorów polskich w przekładach francuskich. Najazd Hitlera na Francję i zajęcie Paryża przerwały tę pracę. W 1941 r. Państwo Kisterowie wylądowali w Nowym Jorku i z miejsca uruchomili wydawnictwo pod firmą «Roy Publishers». W tej kontynuacji «Roju» jeszcze za życia pana Mariana ${ }^{13}$ ukazało się piąte wydanie polskiego oryginału «Soli ziemi». W Nowym Jorku przełożyłem na język polski, też dla pp. Kisterów «Hiroshimę» Johna Herseya ${ }^{14}$.

\section{Polskie oficyny wydawnicze na emigracji}

Po wybuchu wojny poza granicami kraju, głównie w Europie Zachodniej, istniało wiele firm wydawniczych, m.in. Książnica Polska, Biblioteka Polska, Wydawnictwo Światowego Związku Polaków z Zagranicy - „Światopol”, Oficyna Samuela Tyszkiewicza, „Kohorta” Stefana Katelbacha ${ }^{15}$. Aktywnie działał Oddział Kultury i Prasy 2. Korpusu (w tym Biblioteka Orła Białego), Polska YMCA, Związek Harcerstwa Polskiego, Polski Czerwony Krzyż. Do 1945 r. ukazało się kilkaset tytułów, głównie polska klasyka, pozycje dotyczące współczesnej tematyki politycznej, ale i samouczki, podręczniki, informatory i lektury szkolne ${ }^{16}$.

W latach 1945-1949 powstawały nowe firmy wydawnicze, niektóre wywodzące się z oficyn wojskowych, tak jak Polski Związek Wychodźtwa Przymusowego w Hanowerze, który w ciągu dwóch lat swojej działalności wydał 120 książek, Instytut Wydawniczy w Rzymie, potem Paryżu czy przeniesione ze strefy okupacyjnej Niemiec później do Londynu wydawnictwo „Gryf”, specjalizujące się w najnowszej historii Polski. Kilka przedwojennych wydawnictw reaktywowało swoją działalność, m.in. Oficyna Anatola Girsa i Wydawnictwo Polskie

11 H. Kister z córkami dołączyły do M. Kistera (przez Paryż i Hiszpanię) w Portugalii. Potwierdza to Hanna w Pegazach na Kredytowej. W cytowanym źródle J. Wittlin utrzymuje, że nastąpiło to w Paryżu, najprawdopodobniej skracając opis skomplikowanej, w związku z wojną, podróży.

12 Niemcy zlikwidowali wydawnictwo w 1940 r.

13 M. Kister zmarł 6 I 1958 r. w Nowym Jorku.

14 J. Wittlin, Pegazy na Kredytowej, „Wiadomości” 1964, t.19, nr 23 (949), s. 1.

15 M. Pytasz, Wygnanie, emigracja, diaspora: poeta $w$ poszukiwaniu czytelnika, Katowice 1998 , s. 48.

16 A. Kłossowski, Na obczyźnie: ludzie polskiej książki, Wrocław 1984, s. 39. 
R. Wegnera. Wkrótce powstały kolejne wydawnictwa o kluczowym znaczeniu, takie jak Instytut Literacki w Paryżu oraz w Londynie - Katolicki Ośrodek Wydawniczy „Veritas”, Oficyna Poetów i Malarzy oraz Polska Fundacja Kulturalna.

Jednak w USA liczba polskich książkowych wydawnictw emigracyjnych była znacznie niższa, zwłaszcza na początku lat 40. W Nowym Jorku nadal działał Władysław Opaliński, przedwojenny wydawca i księgarz, na emigracji w Ameryce od 1912 r. Jego firma, The Polish Book Importing Company, wydała w tym czasie około 15 książek $^{17}$. Z kolei Polski Instytut Naukowy (PIASA, Polish Institut of Arts nd Sciences in America) powstały w 1942 r. na początku wydawał wyłącznie swoje biuletyny, a założony w 1943 r. Instytut Józefa Piłsudskiego wydał tylko kilka tytułów.

W związku z taką sytuacją, wydawnictwo Roy Publishers mogło rozpocząć działalność w USA bez obaw o konkurencję.

\section{„Roy Publishers” w Nowym Jorku}

Podjęcie działalności wydawnictwa w Nowym Jorku rozważano już w 1938 r. W grudniu tego roku H. Kister przypłynęła do Stanów, aby nawiązać kontakty z Polonią i zorientować się, które z wydanych w dużych ilościach tytułów można byłoby sprzedać na amerykańskim rynku. Po jej powrocie w marcu 1939 r. i wystąpieniu z propozycją założenia filii „Roju” w Stanach, Wańkowicz oskarżył Kisterów o chęć ucieczki z kapitałem z Polski. Do powstania filii nie doszło, ale Kisterowie zdążyli jeszcze wysłać parę tysięcy książek do Maksymiliana Węgrzynka, polskiego wydawcy w Stanach („Nowy Świat”), działacza społecznego Polonii amerykańskiej, współzałożyciela Komitetu Narodowego Amerykanów Polskiego Pochodzenia (KNAPP), Kongresu Polonii Amerykańskiej oraz Instytutu Józefa Piłsudskiego w Ameryce. Węgrzynek miał przeprowadzić kampanię reklamową. Po wybuchu wojny oddał książki do magazynów publicznych na przechowanie, co spowodowało taki wzrost kosztów, że po przyjeździe do Nowego Jorku Kisterowie nie mogli ich odzyskać i byli praktycznie bez grosza ${ }^{18}$.

Z wielkim wysiłkiem rozpoczęli jednak działalność wydawniczą w 1942 r. na 25 West $45^{\text {th }}$ Street (później na 30 East $74^{\text {th }}$ ) publikacją Róży Wiatrów Wierzyńskiego ${ }^{19}$. Na egzemplarzu tego tytułu wydawnictwo funkcjonuje pod nazwą „Rój na Exile”. Potem ukazało się jeszcze pięć innych książek tego autora, między innymi po polsku i po angielsku opowiadanie o wojnie polsko-niemieckiej 1939 r. zatytułowane Pobojowisko, z ilustracjami Zdzisława

\footnotetext{
17 Tamże, s. 234.

18 SPC SUL, M2074, Roy Publishers records. List H. Kister z 12 VIII 1964 r., s. 1.

19 K. Wierzyński, Róża Wiatrów, New York 1942.
} 
Czermańskiego ${ }^{20}$. Kisterowie zaczęli wybierać książki z magazynu, jednak jak wspomina H. Kister, „po zapłaceniu składowego, ogłoszeń, sprzedawców, kosztów handlowych, podróży po Polonii i niezapłaconych rachunków przez różne organizacje, bilans był pod bilansem, raczej dołożyliśmy do tych transakcji”21. Wańkowicz odmówił podjęcia współpracy z „Roy Publishers”.

Początki nie były łatwe. Po przyjeździe do Nowego Jorku, Kister szukał sprzymierzeńców wydawnictwa w agencjach rządowych, zarówno polskich, jak i amerykańskich. W ofercie przedłożonej 1 II 1943 Polish Information Center (PIC), skierowanej na ręce Ludwika Krzyżanowskiego ${ }^{22}$, zaproponował dostarczenie książek autorów międzywojnia ze swojego składu: T. Dołęgi-Mostowicza, Jerzego Marlicza ${ }^{23}$, Juliusza Germana ${ }^{24}$, K. Wierzyńskiego, J. Tuwima, a następnie Krzyżowców Z. Kossak-Szczuckiej, książek A. Fiedlera, J. Lechonia, Henryka Sienkiewicza, Władysława Reymonta, Bolesława Prusa oraz Stownika polsko-angielskiego, Stownika angielsko-polskiego, a także Samouczka polsko-angielskiego.

Kister korzystał z pomocy wspomnianego wcześniej L. Krzyżanowskiego, aby nawiązać kontakt z Ferdinandem Kuhnem, Jr., który wówczas był zastępcą dyrektora Office of War Information ${ }^{25} \mathrm{w}$ celu uzyskania zamówień dla wydawnictwa. W liście z 15 V 1943 r. z Polish Information Center, Kister otrzymał od jego dyrektora - Stefana Roppa, potwierdzenie opłaty honorarium autorskiego, tłumaczenia i zamówienia egzemplarzy książki Zalmana Schneoura Pogrom, wydanej w thumaczeniu jako Song of Dnieper, przekład i adiustację książki Feliksa Grossa, a także zamówienie na wykonanie broszury First to Fight w nakładzie nie mniejszym niż 5 tysięcy. W wyniku otrzymania kredytu od ówczesnego ministra informacji Stanisława Kota, Kister uzyskał zamówienie na wydanie The Black Book of Poland po hiszpańsku i portugalsku ${ }^{26}$.

\footnotetext{
20 SPC SUL, M2074, Roy Publishers records. K. Wierzyński, Wspomnienie o..., s. 1.

21 SPC SUL, M2074, Roy Publishers records. List H. Kister z 12 VIII 1964 r.

22 L. Krzyżanowski przebywał w Stanach Zjednoczonych od 1938 r. jako attaché kulturalny i oświatowy w polskich placówkach dyplomatycznych w Chicago i Nowym Jorku, a w czasie II wojny światowej był pracownikiem PIC.

23 J. Marlicz, pseud. Haliny Borowikowej, znanej jako thumaczka powieści amerykańskiego pisarza i podróżnika Jamesa Olivera Curwooda, opisującego przyrodę i przygody mieszkańców północnej Kanady.

24 J. German, zapomniany pisarz epoki modernizmu okresu międzywojennego, autor dramatów, noweli i opowiadań, którego wszystkie utwory zostały objęte cenzurą w $1951 \mathrm{r}$. i wycofane $\mathrm{z}$ bibliotek.

25 F. Kuhn, dziennikarz specjalizujący się w tematyce międzynarodowej, główny korespondent New York Times w Londynie, w którego biurze pracował od 1936 r. Po powrocie do Waszyngtonu, w latach 1940-43 zajmował stanowisko asystenta Sekretarza Skarbu, a następnie został zastępca dyrektora Office of War Information oraz szefem oddziału brytyjskiego biura.

26 SPC SUL, M2074, Roy Publishers records. Zamówienie z polskiego Ministerstwa Informacji, n.d.
} 
Z zachowanej korespondencji wynika także, że wydawnictwo pertraktowało z amerykańskim War Production Board (WPB) o przydział papieru na druk 100 tys. książek. W liście do Krzyżanowskiego z 13 VII 1943 r., Kister pisze o możliwości dojścia do skutku umowy z Radą Polonii na druk 100000 książek dla polskich żołnierzy na Bliskim Wschodzie, w czym miała pomagać ambasada polska w Waszyngtonie ${ }^{27}$.

W liście do CBW z 22 IV 1944 r. Kister jasno przedstawiał cele wydawnictwa:

W ciągu pięciu lat tysiące polskich żołnierzy i cywilów rozproszyło się po całym świecie i straciło kontakty z ojczyzną, usiłując znaleźć wolność, bezpieczeństwo i inspiracje. Ci Polacy są głodni nowej literatury, książek, które będą nowym źródłem siły stymulacją do przetrwania i życia zgodnego z ich ideałami. Próbujemy zaspokoić ich moralne i intelektualne potrzeby za pomocą polskich książek, ale na razie dysponujemy tylko polską klasykąa ${ }^{28}$.

Podobny list Kister wysłał do wydziału amerykańskiego departamentu ds. nauki, edukacji i sztuki ${ }^{29}$. Jednocześnie przygotował przy pomocy pisarzy i dziennikarzy amerykańskich zestaw książek, obejmujący historię USA, demokrację amerykańską, historię pionierów, udział USA w II wojnie światowej i walce o pokój oraz najlepszych pozycji literatury amerykańskiej, które przybliżyłyby Polakom życie w USA oraz strukturę systemu tego kraju. W liście do L. Krzyżanowskiego z 28 III 1944 r. poinformował o uzyskaniu praw do thumaczenia pierwszej książki z takiej serii, Edwarda Reilly Stettiniusa, Jr., amerykańskiego polityka i sekretarza stanu w latach 1944-45, zatytułowanej Lend-lease: weapon for victory. Jednocześnie Kister planował tłumaczenia tego typu pozycji na inne europejskie języki. Próbował także współpracować z amerykańską Komisją Kontroli Pomocy Wojennej. W liście z 22 IV 1944 r. do Arthura Ringlanda, przewodniczącego komisji, podkreślał, jak ważne było dostarczenie książek rozproszonym w wyniku wojny Polakom, aby utrzymać ich łączność z ojczyzną oraz poszerzyć znajomość historii, kultury i innych aspektów życia mieszkańców USA. „Jestem przekonany - pisał M. Kister w liście - że ten projekt będzie kolejnym krokiem do lepszego wzajemnego poznania mieszkańców obu krajów i spowoduje jeszcze głębszą wdzięczność Polaków za wysiłki USA w budowaniu lepszego świata" ${ }^{30}$. Niestety, pertraktacje nie przyniosły spodziewanych rezultatów. Kister uzyskał z WPB zachętę do wydania tego typu publikacji wyłącznie na własną rękę, na co wówczas nie mógł sobie pozwolić.

\footnotetext{
27 SPC SUL, M2074, Roy Publishers records. List do L. Krzyżanowskiego z 13 VII 1943 r.

28 Tamże.

29 SPC SUL, M2074, Roy Publishers records. List z 22 IV 1944 r.

30 A. Ringland kierował różnymi programami rządowymi, m.in. mającymi związek z pomocą dla uchodźców. W 1945 r. opracował koncepcję prywatnej organizacji wolontariackiej, znanej pod nazwą CARE. Głównym aspektem tej pracy było przekonanie rządu do opłacenia statków dostarczających pomoc dla Europy. Jego wysiłki zostały nagrodzone przyznaniem odznaczenia przez Zgromadzenie Narodów Zjednoczonych w 1958 r.
} 
W celu pozyskania funduszy na prace wydawnictwa, Kister dostarczał książki do emigracyjnych księgarni, m.in. do Edynburga i do Księgarni Polskiej „Co Słychać” ${ }^{1}$. Sytuacja finansowa wydawnictwa poprawiła się wraz z opublikowaniem wspomnień R. Langer zatytułowanych Syrenka i Messerschmitt, o bombardowaniu i spaleniu Warszawy przez Niemców ${ }^{32}$ oraz jej thumaczenia książki Kossak-Szczuckiej Bez oręża $a^{33}$, która w kwietniu tego roku została wybrana przez Council on Books in Wartime na książkę miesiąca. Spowodowało to wzrost znaczenia wydawnictwa, które zaczęło być rozpoznawalne w USA. Dowodzą tego listy m.in. z Office of War Information (OWI) i Council on Books in Wartime (CBW). Krzyżanowski w liście z 30 III 1944 r. pisze: „Wszyscy tutaj [w OWI - przyp. autorki] czytali Blessed are the Meek i to przedstawia Pana najlepiej". ${ }^{34}$ Natomiast Archibald G. Ogden, dyrektor Generalny CBW w liście z 29 III 1944 r. stwierdza, że w porównaniu do innych wydawnictw „Roy Publishers” uzyskało znakomitą pozycję w USA z godną pozazdroszczenia szybkością. ${ }^{35}$

„Roy Publishers” kontynuowało tradycję wydawania polskich tytułów, ale w przekładach na język angielski. Publikowało utwory pisarzy z grupy Skamandrytów (ze względu na posiadane prawa autorskie jeszcze z przedwojennego „Roju”) w angielskich przekładach, nie tylko powieści, nowele, poezję, lecz także literaturę dla dzieci (autorstwa Janiny Porazińskiej, I. Lorentowicz, E. Szelburg-Zarembiny). W jednym z katalogów zapowiadających nowości wydawnicze na jesień i zimę 1944 r. można znaleźć książki promujące polską naukę, historię, sztukę, kulturę i literaturę oraz reportaż. Są to: Poland Fights Back Pruszyńskiego z ilustracjami Hugo Steinera-Praga, The Forgotten Battelfields Wierzyńskiego z ilustracjami Czermańskiego, Freedom and Civilization Bronisława Malinowskiego, Life and Culture of Poland Wacława Lednickiego, Copernicus and His World Hermanna Kestena (książka polecana przez Tomasza Manna w zamieszczonej na okładce nocie wydawniczej), Journeying Through Polish Art Ireny Piotrowskiej, I Lived a Lie A. Janty-Połczyńskiego, A History of Poland Oskara Haleckiego. W innym katalogu, z książkami wydanymi w latach 1943-44, zamieszczone są następujące tytuły „Royu”: Modern Warfare gen. Władysława Sikorskiego, Tales of the Tatras Kazimierza Przerwy-Tetmajera, Conrad and His Contemporaries Józefa H. Retingera, z ilustracjami F. Topolskiego, polskiego malarza ekspresjonistycznego, The Black Book of Polish Jewry

31 SPC SUL, M2074, Roy Publishers records. List z Księgarni Polskiej z Edynburga z 17 VII 1946 r. do Roy.

32 R. Langer, The Mermaid and the Messerschmmitt, New York 1942.

33 Z. Kossak, Blessed are the Meek, thum. R. Langer, New York 1944.

34 SPC SUL, M2074, Roy Publishers records. List z 30 III 1944 r. od L. Krzyżanowskiego.

35 SPC SUL, M2074, Roy Publishers records. List z 22 IV 1944 r. do Council on Books in Wartime. 
Jacoba Apenszlaka (o niemieckiej polityce eksterminacyjnej), Where the Storm Broke Stanisława Strzetelskiego, Squadron 303 A. Fiedlera, The Mermaid and the Messerschmitt R. Langer oraz książki dla dzieci: J. Porazińskiej My Village i In Voytus'Little House, King Mathews I Janusza Korczaka, Lullaby: Why the Pussy-Cat Washes Himself So Often, bajki ludowej zaadaptowanej z języka polskiego na angielski przez Josephine B. Bernhard z ilustracjami I. Lorentowicz. Ta ostatnia znalazła się na liście 100 najlepszych książek dla dzieci, ogłoszonej przez the New York Children's Library Association ${ }^{36}$.

Jeden z dokumentów w języku angielskim zawiera notatkę sprawozdawczą dotyczącą działalności wydawniczej od 1940 do 1950 r. (mimo iż lata nie są podane, zgodnie z informacją o opublikowanych tytułach, należy wnioskować, że mowa jest o tym okresie):

W ciągu tych dziesięciu lat, Marian i Hanna Kisterowie kontynuowali w Ameryce ideały i pojęcie roli wydawcy w życiu kulturalnym kraju, które najpierw rozwinęli w Polsce. Postrzegają książkę jako główne narzędzie pozwalające na wzbogacenie zrozumienia i wiedzy ludzkiej, co jest podstawą zachowania pokoju na świecie. Lista ich publikacji pokazuje, że przedstawili czytelnikom amerykańskim dzieła znakomitych pisarzy i myślicieli polskich, włoskich, francuskich, holenderskich, jugosłowiańskich $\mathrm{i}$ angielskich z dziedziny literatury, biografii i historii. Zaprezentowali Ameryce, a tym samym wzbogacili jej życie kulturalne, ilustracje czterech wybitnych polskich artystów ${ }^{37}$. W Polsce prezentowali rodakom najlepsze dzieła pisarzy oraz autorów europejskich $i$ amerykańskich, a w Ameryce kontynuowali swoje wysiłki w tym samym duchu ${ }^{38}$.

Warszawskie wydawnictwo na emigracji kontynuowało tradycję publikowania książek twórców europejskich, zarówno z krajów zachodnich, jak i wschodnich. W dorobku wydawnictwa są publikacje popularnonaukowe, prace dotyczące historii, seksualności czy psychologii oraz książki biograficzne, reportażowe, o tematyce krytyczno-literackiej, antologie oraz literatura dla dzieci. Wykaz opublikowanych w tym czasie książek obejmuje m.in.: Homo Ludens: zabawa jak źródło kultury Johana Huizingi, serię powieściopisarzy europejskich, w której Kisterowie opublikowali utwory Andre Gide'a, Stendhala, Fiodora Dostojewskiego i Marcela Prousta, serię angielskich autorów, prezentującą Karola Dickensa, Wilkie Collinsa, Gustawa Le Bona, Ronalda Firbanka oraz Pierwsze dzieci Boga Esther Salminen (1946).

36 SPC SUL, M2074, Roy Publishers records. List z 16 V 1945 r., zaadresowany „Dear Editor”, polecający twórczość I. Lorentowicz.

37 Chodzi tu o I. Lorentowicz, Janinę Konarską, ilustratorkę Tales of Tatras, Zdzisława Czermańskiego, Stanisława Bobińskiego, ilustratora książek Janiny Porazińskiej. Do grona tego należy również dodać Anielę (Lelę) Pawlikowską, ilustratorkę książek i portrecistkę, zamieszkałą po II wojnie światowej w Londynie.

38 SPC SUL, M2074, Roy Publishers records. Notatka przygotowana przez wydawnictwo, n.d. [Dokument przetłumaczony przez autorkę]. 
Motorem wydawnictwa, także w Nowym Jorku był Kister. W jego prowadzeniu pomagała mu żona. Oboje kontaktowali się ze swoimi autorami, księgarzami, wydawcami i przyjaciółmi, co wynika z listów i kartek pocztowych znajdujących się w kolekcji. Często jeździli do Polski, łudząc się, że uda się coś jeszcze z dawnego wydawnictwa uratować. W drugiej połowie lat 40. założyli nawet wspólnie z Wańkowiczem małą komórkę „Roju”. Szybko jednak musieli ją zlikwidować ze względu na bezpieczeństwo pracowników ${ }^{39}$. Ze wspomnień o wydawcach wynika jasno, że adaptowali warszawskie tradycje w Nowym Jorku. Jak pisze Wierzyński:

Z braku nieznanej w Nowym Jorku instytucji, jaką jest kawiarnia, Kister ściągał ludzi do siebie do domu na niekończące się pogawędki. U państwa Kisterów spotkać można było Kuncewiczową, Lorentowiczównę, Lednickiego, Lechonia, Wittlina, Jantę, aktora Rozmarynowskiego, Solskiego, Strzetelskiego, a z obcych Kestena, panią Virgilię Peterson, Don Luigi Sturzo.

Można też było tam popić, najeść się, a nawet przespać. Był to dom nieznający granic gościnności. Kister występował tam również w charakterze kucharza, miał swoje specjalności kulinarne i nie wolno nie było przyjąć jego zaproszenia, nawet gdy gość zjawiał się nieprzewidziany, na pięć minut przed obiadem czy kolacją.

Kister prowadził «Rój» przy pomocy swojej żony. Ta wiecznie młoda i niewyczerpana w energii osoba zbierała materiały, utrzymywała kontakty z pisarzami i wydawcami polskimi i amerykańskimi, jeździła po Stanach i po świecie. Ostateczna decyzja należała jednak do Kistera. Pobierał ją łatwo, jakby od niechcenia, a w każdym razie bez lęku, bez nerwów, bez napięcia. Nie pasowała do niego żadna uroczysta toga, wierzył w swoją gwiazdę i - jak to się mówi - miał szczęście. Z bardzo trudnych warunków w Nowym Jorku potrafił wydobyć się nie tylko na wierzch, ale także znaleźć miejsce dla swojego «Roju» wśród publikacji amerykańskich. «Roy» nowojorski wydał w sumie 90 książek polskich i 800 angielskich.

Kister miał jeszcze jedną rzecz uderzającą: niezwykle trafny sąd krytyczny o książkach. Czy to był tzw. nos, czy obycie w pracy, czy po prostu talent, nie umiem określić. Dość, że osądzał rzecz szybko i bez trudu.

Umiał też fenomenalnie liczyć w pamięci i gdy pani Kisterowa przynosiła mu jakiś rękopis maszynowy, patrzył na ilość stron i natychmiast wymieniał sumę kosztów produkcji ${ }^{40}$.

Po śmierci Kistera w 1958 r. prezesem wydawnictwa została jego żona. W 1963 r. z okazji 40-lecia działalności wydawnictwa i w celu upamiętnienia męża ustanowiła nagrodę „Royu” za tłumaczenia, kontynuując tym samym promocję polskiej literatury.

H. Kister szukała niestrudzenie nowych rynków wydawniczych. Podczas podróży w 1967 r. odwiedziła domy wydawnicze w Japonii, następnie w Madrasie, Mumbaju, New Delhi, Kalkucie, a w drodze powrotnej - w Teheranie

39 SPC SUL, M2074, Roy Publishers records. List H. Kister z 12 VIII 1964 r., s. 1.

40 SPC SUL, M2074, Roy Publishers records. K. Wierzyński, Wspomnienie o..., s. 2-3. 
i Istambule. W wyniku tej podróży podjęła decyzję kontynuowania tradycji wydawania literatury dziecięcej, ale tym razem w Indiach i w języku angielskim. Partnerką tego przedsięwzięcia została Shrimati Mrinalini Sarabhai z Ahmedabad w Indiach, renomowana tancerka i autorka książki o Bharata Natyam, klasycznym stylu tańca hinduskiego, zaangażowana w różnego rodzaju przedsięwzięcia edukacyjne w Indiach. Córki Hanny objęły w wydawnictwie różne funkcje: Irena, żona Cesare T. Lombroso - doradcy wydawniczego, a Elżbieta, żona George'a W. Clarka - dyrektora artystycznego. Wydawnictwo przyjęło nazwę „Mrinal - Roy Publishers International (P), Ltd or MRI. Jego celem była publikacja wysokiej jakości książek w języku angielskim, po niewysokiej cenie, pisanych i zaprojektowanych tak, aby przedstawić najlepsze wartości życia i sztuki w Indiach, z dystrybucją w USA, Wielkiej Brytanii i w Indiach. Ponadto MRI nawiązało współpracę z grupą lokalnych wydawców, publikujących książki w 14 językach. Kooperacja ta miała umożliwić przedstawienie książek amerykańskich w Indiach i odwrotnie, a tym samym - umożliwić wymianę idei i informacji między dziećmi na całym świecie ${ }^{41}$.

\section{Działalność promocyjna}

Wydawnictwo informowało o swoich publikacjach i promowało je rozsyłając katalogi wydawnicze, co dotyczyło także tłumaczeń międzywojennej literatury polskiej. Korzystało też z usług różnego rodzaju stowarzyszeń księgarskich i bibliotecznych, które zamieszczały spisy publikowanych lub planowanych do publikacji książek. Kolekcja zawiera przykłady takiej korespondencji, m.in. list z „The Book Buyer's Guide”, Carl J. Leibel, Prebound Juvenile Books w Los Angeles, oferujący usługę zamieszczenia tytułów publikowanych przez „Roy”. Była to usługa pozwalająca wydawcom dotrzeć do odbiorców po zmniejszonych kosztach, unikając drukowania i rozsyłania katalogów drogą pocztową. Zamieszczenie jak największej liczby tytułów w tego typu publikacjach było więc doskonałą promocją. Archiwum zawiera bogatą korespondencję z tego rodzaju instytucjami i jak wynika z podpisów pod listami, zajmowała się tym głównie $\mathrm{H}$. Kister, a w miarę rozwoju firmy pracownicy wydawnictwa.

Rozległa korespondencja z instytucjami amerykańskimi mieszcząca się w kilkunastu folderach zawiera propozycje recenzji książek oraz zamówienia publikacji wydanych w Europie, zwłaszcza popularnonaukowych dla dzieci i młodzieży oraz dla dorosłych. Jest to świadectwo kontynuowania tradycji popularyzacji nauki wydawnictwa z okresu międzywojennego. Listy pochodzą z organizacji młodzieżowych, takich jak: Boy Scouts of America, Girl

41 SPC SUL, M2074, Roy Publishers records Around the World - Spring 1967, s. 1-3. 
Scouts of America, periodyków: „Peabody Journal of Education”, „Journal of American Folklore”, „American Sociological Review”, „Music News”; agencji rządowych i stanowych: Departament of Education stanu Minnesota, U.S. Department of Health, Education and Welfare; stowarzyszeń: The American Folklore Society; uczelni: New York University, Boston College, itp. Przykłady takich tytułów to wspomniany już Homo Ludens Huizingi oraz pozycje innych autorów europejskich, takich jak Folk Tales From Roumania Iona Creanga, czy The Story of Ships oraz The Story of Aircraft S.E. Ellacotta. W archiwum zachowały się listy adresowane do i otrzymane od „Publishers' Weekly”, spisy książek prezentowanych na imprezach, m.in. w Muzeum Nauki i Przemysłu w Chicago pt. Miracle of Books Fair for Boys and Girls (Cuda targów książek dla dziewcząt i chłopców), który odbył się w dniach 14-22 XI 1953 r. (na liście znajdują się książki Porazińskiej, Haliny Górskiej i Lorentowicz).

Recenzje tytułów „Royu” w prasie krajowej, od Los Angeles, przez Chicago, do Nowego Jorku, były pracowicie wycinane i naklejane na tekturę. Jednym z typowych przykładów takich udokumentowanych pozycji jest książka Kossak-Szczuckiej, The Covenant (Przymierze), przetłumaczona na angielski przez H.C. Stevensa. W zbiorach znajdują się wycinki pochodzące z różnych gazet. Innym przykładem promocji jest dokumentacja poświęcona Zmowie nieobecnych (Conspiracy of the Absent) Kuncewiczowej, zawierająca wycinki m.in. z nowojorskiego „Book Review Digest” i „Boston Traveler”. Kolejnym przykładem dobrze przygotowanego materiału promocyjnego jest list Kisterowej do Art Klubów z propozycją sprzedaży książek Janty z autografami pisarza. Wydawnictwo przygotowało także z tej okazji specjalne drukowane karty z formularzem zamówienia. Wydawnictwo skrzętnie kolekcjonowało recenzje i informacje książek publikowanych przez siebie autorów, a każdy $\mathrm{z}$ nich posiadał osobny folder.

W celach promocyjnych i informacyjnych Kisterowie wysyłali książki do instytucji polskich, takich jak Ambasada Polski w Waszyngtonie (list z podziękowaniem za Dywizjon 303 z 6 I 1943 r. od zastępcy attaché lotniczego, Witolda Urbanowicza), czy periodyków emigracyjnych: „Kuriera Codziennego” (Boston), „Wiadomości” (Londyn), „Nowego Światu” (Nowy Jork). W jednym z zachowanych egzemplarzy „Nowego Światu” z 10 IX 1953 r. znajduje się omówienie wydawanych wówczas tytułów polskich lub o polskiej tematyce, m.in. wydanej przez „Roy” książki Jerzego Pietrkiewicza The Knotted Cord, która stała się sensacją literacką, a młody autor ze względu na stopień opanowania języka angielskiego został porównany do Conrada Korzeniowskiego. 
Udział w amerykańskich wydarzeniach branżowych

Z korespondencji wynika, że wydawnictwo uczestniczyło w amerykańskich wydarzeniach branżowych, organizowanych przez Children's Book Council, Women's National Book Association, American Book Publishers Council, czy PEN Club. W wydanym 6 IX 1952 r. „Publishers' Weekly: the American Book Trade Journal" znajduje się zdjęcie H. Kister, słynnej z polskiej gościnności, która jako aktywny członek tej organizacji przygotowała w swoim letnim domu w Vermont doroczne zebranie WNBA (Women's National Book Association), organizacji non-profit promującej od 1917 r. kobiety w świecie książki ${ }^{42}$.

\section{Udział w życiu polonijnym}

Kisterowie korespondowali aktywnie z polskimi i polonijnymi organizacjami oraz uczestniczyli w polonijnych wydarzeniach. Kilka folderów zawiera prowadzoną w latach 1943-1956 korespondencję w języku polskim i angielskim z organizacjami, m.in. z Radą Polonii Amerykańskiej (The Polish-American Council) w Waszyngtonie, Ambasadą Polski, American Polish War Relief (i podobnymi organizacjami); Związkiem Polek w Ameryce (Polish Women's Alliance of America), łącznie z listami Adeli Łagodzińskiej, prezeski tego związku w latach 1947-1971. Kisterowie uczestniczyli także w imprezach polonijnych w Nowym Jorku, m.in. w wystawach malarstwa, wieczorach autorskich i prelekcjach, prezentujących, promujących oraz wspomagających przedstawicieli polskiej kultury na emigracji: m.in. Hemara (pod egidą przedwojennego krakowskiego kabaretu Zielony Balonik, który miał kilka przedstawień w Nowym Jorku), Wierzyńskiego, Wańkowicza i Lorentowicz.

\section{Nagrody za przekłady literackie}

Po śmierci męża H. Kister ufundowała dorocznie przyznawaną podczas uroczystego obiadu w nowojorskim PEN Clubie nagrodę za przekłady literatury $\mathrm{z}$ angielskiego na polski i z polskiego na angielski. Do pierwszego konkursu mogli przystąpić autorzy książek wydanych w latach 1961-63. Był to kolejny znakomity sposób na przybliżenie czytelnikom amerykańskim polskiej literatury w przekładzie, a czytelnikom polskim - literatury angielskiej i amerykańskiej. Kisterowa osobiście wysyłała informacje o nagrodzonych przekładach do prasy emigracyjnej z prośbą o zamieszczenie komunikatów, m.in. do „Dziennika Polskiego i Dziennika „Żołnierza”, „Wiadomości” Mieczysława

42 SPC SUL, M2074, Roy Publishers records. WNBA Holds Annual Outing At Kister Vermont Farm. „Publisher's Weekly: the American Book Trade Journal”, s. 97. 
Grydzewskiego w Londynie (oba listy z kwietnia 1964 r.) oraz do PEN Clubu w Warszawie (niedatowany telegram o przyznaniu podzielonej nagrody za całokształt pracy Bronisławowi Zielińskiemu i Krystynie Tarnowskiej).

Skład jury zmieniał się co roku, a wydawnictwo zapraszało do niego najlepszych polskich i amerykańskich pisarzy, poetów, tłumaczy oraz profesorów literatury z uniwersytetów w Polsce i USA. W 1963 r. jury w składzie: A. Janta, Virgilia Peterson-Sapieha (pisarka amerykańska i dziennikarka telewizyjna) i Robert Penn Warren (amerykański pisarz, poeta i krytyk literacki, laureat Nagrody Pulitzera w 1947 r. za All the King's Men), przyznało nagrodę Celinie Wieniawskiej za thumaczenie Sklepów Cynamonowych (Street of the Crocodiles) Brunona Schulza. Wieniawska, zamieszkała w Londynie, była już wtedy autorką thumaczenia Przeminęto $z$ wiatrem (Gone with the Wind) Margaret Mitchell, Lata $w$ Nohant (Summer in Nohant) Jarosława Iwaszkiewicza oraz Zdobycia władzy (The Usurpers) Czesława Miłosza. W tym samym roku

Do nagrody przedstawione były dzieła wybitnych pisarzy polskich przedwojennych, jak Stanisław Ossowski, wybitny socjolog, Witold Gombrowicz, Maria Kuncewicz, Jerzy Andrzejewski, Bruno Schulz i powojennych: Tadeusz Nowakowski, Sławomir Mrożek, Stanisław Lec, Adam Gillon, Czesław Miłosz, Leopold Tyrmand, Kazimierz Brandys, Jan Dobraczyński, Józef Mackiewicz i Zofia Romanowicz ${ }^{43}$.

Nagrodzeni za tłumaczenia z angielskiego na polski K. Tarnowska i B. Zieliński posiadali imponujące osiągnięcia: Tarnowska przełożyła 20 książek, m.in. Thomasa Wolfe'a, Malcolma Lowry'ego, J. Cronina, Marka Twaina, Erskine'a Caldwella, a Zieliński - 40, m.in. E. Hemingwaya, J. Steinbecka, A. Huxleya, R. Penna Warrena. W jury zasiadali: J. Wittlin, polski pisarz i poeta, autor Soli ziemi, na emigracji w Nowym Jorku i M. Kuncewiczowa, polska pisarka, autorka m.in. Cudzoziemki.

W kolejnej edycji konkursu w 1965 r. nagrodzono thumaczenie epopei Adama Mickiewicza Pan Tadeusz, or the Last Foray in Lithuania, wykonane przez Kennetha R. Mackenziego. Książka wydana została przez Polish Cultural Foundation w Londynie, z amerykańskim wydaniem opublikowanym przez E.P. Dutton \& CO., Inc. w Nowym Jorku. Przekład rozszedł się w Londynie w kilka tygodni i uzyskał świetną recenzję w „The Times Literary Supplement” gdzie został określony jako „bezsprzecznie najlepszy ze wszystkich dotychczasowych przekładów wierszem" ${ }^{44}$. W uzasadnieniu przyznania nagrody podkreślono niezwykle dokładny i z zachowaniem niuansów przekaz znaczenia oraz odtworzenie w języku obcym rytmu polskiego oryginału, uchwyconemu jednocześnie łatwo, ale i wzniośle. W skład jury wchodzili: Beatrice J. Chute

43 SPC SUL, M2074, Roy Publishers records. Informacja o rozdaniu dorocznych nagród za najlepsze tłumaczenia przez Roy Publishers, Inc.

44 SPC SUL, M2074, Roy Publishers records. Informacja przygotowana dla prasy. 
(powieściopisarka i nowelistka, autorka Greenwillow, prezydent PEN w latach 1959-1961), profesor Wiktor Weintraub z Harwardu i profesor Ihor Sevcenko z Dumbarton Oaks w Waszyngtonie. Wyróżnienie otrzymał David Welsh za thumaczenie Wyspy ocalenia (Island of Salvation) Włodzimierza Odojewskiego. W tej samej edycji konkursu, za przekład Króla Leara i Hamleta Williama Szekspira z języka angielskiego na polski nagrodę otrzymał profesor Witold Chwalewik z Katolickiego Uniwersytetu Lubelskiego. W jury zasiadał Paweł Mayewski, redaktor nowojorskich „Tematów”, i profesor Irena Sławińska z Katolickiego Uniwersytetu Lubelskiego ${ }^{45}$. W kolejnych latach nagrodzono Puppy Years czyli Szczenięce lata M. Wańkowicza w thumaczeniu B.W.A. Masseya (profesora wydziału literatury angielskiej Uniwersytetu im. A. Mickiewicza w Poznaniu w latach 1921-1939 i 1946-1950, a także thumacza polskiej literatury: Sienkiewicza, Kuncewiczowej oraz polskich badaczy, specjalizujących się w stosunkach polsko-niemieckich i historii Polski) ${ }^{46}$ oraz Strasznego dziadunia (The Student and the Squire) Marii Rodziewiczówny w przekładzie Eileen Arthurton i Norberta Reha.

Do nagrody nominowani byli inni polscy pisarze i tłumacze, m.in. Maria Skibniewska za przekłady m.in. Buszujacego w zbożu (The Catcher in the Rye) J.D. Salingera, Aleksandra Frybesowa za Sancheza i jego dzieci (The Children of Sanchez) Oscara Lewisa. Przekłady polskiej literatury prezentowały czytelnikom anglojęzycznym twórczość Jana Kotta, Jana Dobraczyńskiego, Józefa Mackiewicza, W. Odojewskiego, Michała Choromańskiego i wielu innych.

W maju 1970 r. ogłoszono nagrody za lata 1969-1970. W jury przyznającym nagrody w dziedzinie przekładów literatury polskiej na angielski zasiadali: Cz. Miłosz (poeta, pisarz i profesor Uniwersytetu Kalifornijskiego w Berkeley), Wacław Iwaniuk (poeta, thumacz i eseista) oraz Aleksander Leyfell (dyplomata, później redaktor Państwowego Instytutu Wydawniczego w Warszawie, po 1968 r. na emigracji). Nagrody przyznano pierwszym tłumaczom utworów Stanisława Ignacego Witkiewicza, znanego polskiego dramaturga okresu międzywojennego: Danielowi C. Gerouldowi (dramaturgowi i profesorowi State College w San Francisco, Kalifornia) za Wariata i Zakonnice (ang. The Madman and the Nun) oraz C.S. Durerowi (wykładowcy Uniwersytetu w Berkeley).

45 SPC SUL, M2074, Roy Publishers records. Memo Roy Publishers zawiadamiające o przyznaniu nagrody, przygotowane do publikacji $2 \mathrm{~V} 1963 \mathrm{r}$.

46 History of the School of English and the Faculty of English. Strona internetowa Wydziału Anglistyki Uniwersytetu im. Adama Mickiewicza w Poznaniu, [online] http://wa.amu.edu.pl/wa/history_historia [dostęp 20.05.2018]. 


\section{Podsumowanie}

Archiwum wydawnictwa „Roy Publishers” jest cennym źródłem do badań historii dziedzictwa kulturalnego II Rzeczpospolitej na emigracji. Zawarte w nim materiały źródłowe są dowodem kontynuacji idei przyświecającym „Rojowi” w okresie międzywojennym, takich jak dostęp masowego czytelnika do literatury ojczystej i obcej na dobrym poziomie, popularyzacja nauki, publikacja wartościowej literatury dziecięcej oraz dostęp do informacji o innych kulturach i wartościach. W Polsce międzywojennej wydawnictwo „Rój” udostępniało masowym czytelnikom dzieła najlepszych autorów polskich oraz dzieła pisarzy europejskich i amerykańskich. Mimo krótkiej tradycji, ze względu na liczbę i poziom literacki wydanych przed wojną tytułów nie miało sobie równych.

Wydawnictwo „Roy Publishers” powoływało się na związek z przedwojennym „Rojem”, aby podkreślić tradycje związku jego pracy z przedwojenną Polską. Tytuły wymieniane w katalogach z lat 1940-1960, które znajdują się w kolekcji, potwierdzają jego wkład w promocję najwybitniejszych twórców polskiej literatury, kultury i nauki. Wybór polskich autorów i tematyki polskich książek publikowanych w przekładzie na angielski, przybliżył czytelnikom amerykańskim Polskę i Polaków. Ustanowienie w 1963 r. nagrody za przekłady literatury polskiej na język angielski i angielskiej na polski, wspomogło to przedsięwzięcie oraz pomogło czytelnikom polskim poznać literaturę angielską i amerykańską w najlepszych tłumaczeniach. Wydawanie tytułów autorów europejskich w przekładach na angielski, piszących na tematy popularnonaukowe jest wyraźną kontynuacją tradycji warszawskiego wydawnictwa na obczyźnie. Podejmowane przez Kistera próby publikacji książek o historii, polityce i ideałach demokracji amerykańskiej, choć niezrealizowane, wskazują na przyświecający mu cel zapewnienia rodakom-emigrantom dostępu do informacji o nowej ojczyźnie.

Z kolei eksploracja rynku wydawniczego w Azji, a zwłaszcza w Indiach, przez H. Kister w drugiej połowie lat 60 . i plany publikacji książek po niewysokiej cenie, czyli dla masowego odbiorcy są kontynuacją wartości wydawnictwa z okresu międzywojnia. Tak jak przed wojną „Rój” przedstawiał Polakom literaturę amerykańską i europejską, a po wojnie czytelnikom amerykańskim - polską, Kister dążyła do przybliżenia nieznanej kultury Indii czytelnikom w USA i Wielkiej Brytanii. 


\section{Bibliografia}

[admin.], Marian Kister. Wielki zapomniany wydawca, wspólnik Melchiora Wańkowicza. PodkarpackaHistoria.pl, 2 lipiec 2017 [online] http://www.podkarpackahistoria. pl/2017/07/marian-kister-wielki-zapomniany-wydawca-wspolnik-melchiora-wankowicza/ [dostęp 20.05.2018].

[kr.] Zastużone dziesięciolecie: wywiad z Tow. Wydawniczem „Rój”, „Wiadomości Literackie" 1935, nr 10, s. 5.

Department of Special Collections and University Archives Stanford University Libraries, catalog number M2074, Roy Publishers records, undated [stan z lutego 2017 r.].

History of the School of English and the Faculty of English. Strona internetowa Wydziału Anglistyki Uniwersytetu im. Adama Mickiewicza w Poznaniu, [online] http://wa.amu. edu.pl/wa/history_historia [dostęp 20.05.2018].

Janta A., Wspomnieniu o moim wydawcy (fragment pamiętnika), „Tydzień Polski”, 21 IX 1968 r., Londyn.

Kister H., Pegazy na Kredytowej: wspomnienia, Warszawa 1980.

Kłossowski A., Na obczyźnie: ludzie polskiej ksiazzki, Wrocław 1984.

Kraśko N., Instytucje wydawnicze w II Rzeczypospolitej, Warszawa 2001.

Krupa B., Nafpaktitis M., Polonika w Bibliotece Uniwersytetu Stanforda w Kalifornii: unikalne kolekcje, trudności w gromadzeniu i udostępnianiu. „Z Badań nad Książką i Księgozbiorami Historycznymi" 2017, t. specjalny: Polonika w zbiorach obcych, red. nauk. J. Puchalski, A. Chamera-Nowak i D. Pietrzkiewicz, Warszawa 2017, s. 557-566.

Pytasz M., Wygnanie, emigracja, diaspora: poeta w poszukiwaniu czytelnika, Katowice 1998.

Wittlin J., Pegazy na Kredytowej, „Wiadomości” 1964, t. 19, nr 23 (949). 